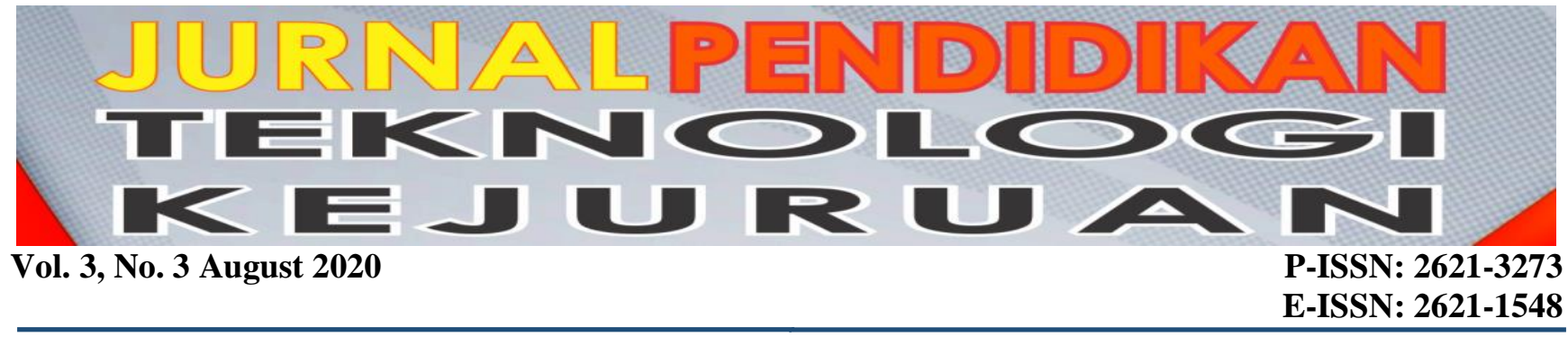

\title{
Development of Practice Module on Domestic Electricity Installation Based Project on Electrical Engineering Students
}

\author{
Yusuf Fornando ${ }^{1 *}$, Ahayanuardi ${ }^{2}$ \\ ${ }^{123}$ Department of Electrical Engineering, Universitas Negeri Padang \\ "Corresponding author, e-mail: fornandoyusuf@gmail.com ${ }^{1}$
}

\begin{abstract}
Based from observation of the learning process of the Domestic Electrical Installation Practice of vocational students of the Electrical Engineering Study Program, Faculty of Engineering, Padang State University shows that the learning process is not optimal because of practical learning unchallenged students to be creative in planning and implementing Domestic Electrical Installation Practices. The research objective is to develop a project-based practice module that can improve student learning outcomes in the learning process of the Domestic Electrical Installation Practice. Research with Four-D design is applied to develop and test the validity, practicality, and effectiveness of project-based practice modules in learning domestic electrical installation practices. The stages of the research include defining, designing, developing, and distributing. The results of testing the validity of project-based practices indicate that the learning media is valid. These aspects are material, media aspects, and language aspects. Indicates that the project-based practice module is valid to apply in the learning process of Domestic Electrical Installation Practices. The result the data analysis shows that the practice module developed in the Domestic Electrical Installation Practice learning process is valid, it can be concluded that the project-based practice module is valid for use in the learning process Domestic Electrical Installation for Electrical Engineering Study Program students.
\end{abstract}

Keywords: practice module, project based learning, electrical engineering

Copyright @ 2020 JPTK. All rights reserved

\section{INTRODUCTION}

The Domestic Installation Practice Course is one of several practical courses that need to be followed and studied by every student of the Electrical Engineering Study Program which aims to provide students with competency expertise in the field of lighting installations both on the domestic and industrial lighting scale. Learning Outcomes in this course students are able to design single line diagrams, wiring diagrams, power calculations and choices for residential installations, students are able to install electrical installations based on work safety standards and PUIL standards, and students are able to test and measure the feasibility of domestic electrical installations based on procedures and standards.

From the learning achievements of the domestic electrical installation course, it can be seen that there are no students who are able to plan and implement electrical installations. In addition, they have not been able to design electrical installations and present the design results in the form of engineering and electrical drawings. One of the reasons is that there is no appropriate learning module to support learning outcomes at level 5 KKNI. Based on the results of observations and interviews conducted with lecturers who teach Installation Practice courses, so far the available practice modules only teach students as executors or executors, namely only making a series based on the pictures provided. The available practical modules have not been able to accommodate students' analytical and planning skills in the domestic installation field. So that at the end, when asked to design a domestic installation, it encountered difficulties and ended up getting a nonoptimal value which indicated that the learning outcomes had not been achieved.

Then based on observations and interviews of several students who were carried out during the practice on October 18, 2019, it was seen that students during practice tended to only assemble according to the series image on the existing circuit board. Of course, the general and specific skills aspects in level 5 KKNI cannot be achieved properly because students should be able to design and plan electrical installations. On the other hand, practical learning activities do not challenge students to be 
creative to be able to plan and carry out domestic installations, so that the achievement of learning outcomes is less than optimal. The following is the percentage of learning outcomes in the Domestic Electrical Installation Practice of Electrical Engineering Study Program students.

Tabel 1. Percentage of Learning Outcomes for

Domestic Electrical Installation Practices for

Electrical Engineering Study Program Students

\begin{tabular}{lllllll}
\hline Acade & $\begin{array}{l}\text { Number } \\
\text { mic }\end{array}$ & \multicolumn{5}{l}{ Amount / Percentage of Student Score } \\
\cline { 3 - 6 } Year & $\begin{array}{l}\text { of } \\
\text { Students }\end{array}$ & A & A- & B & B & $<=$ B- \\
\hline 2017 & 57 & 5 & 7 & 15 & 15 & 15 \\
\cline { 3 - 7 } & & 8,7 & 12,3 & 26,3 & 26,3 & 26,3 \\
\hline 2018 & 52 & 7 & 3 & 10 & 22 & 10 \\
\cline { 3 - 6 } & & 13,5 & 5,7 & 19,2 & 42,3 & 19,3 \\
\hline 2019 & 55 & 4 & 8 & 22 & 11 & 10 \\
\cline { 3 - 6 } & & 7,3 & 14,5 & 40 & 20 & 18,2 \\
\hline
\end{tabular}

Source: Domestic Installation Practice Lecturer Documentation.

The learning results in Table 1 indicate that the implementation of the Domestic Electrical Installation Practice learning process is not optimal due to the unavailability of practice modules that are able to accommodate the overall learning outcomes of domestic installation practice. So far, in preparation for the practical implementation, students are asked to follow all the work steps in the jobsheet without making their own installation plans, in the implementation of students only following lecturers' directions and existing work steps so that in the evaluation they cannot see the ability of students to plan and analyze problems. in installation. To be able to solve this problem, a practical module is needed that refers to the learning outcomes in KKNI level 5.

A practical module that not only gives students the ability to assemble but can also foster creativity and implementation of large-scale installation works starting from planning, implementing, testing, and making improvements. One alternative option is a project-based practice module. The project-oriented learning process is a learning process that is appropriate to be applied and implemented in a productive learning process that not only hones theoretical skills but also emphasizes practical skills in accordance with the field being studied. The project-based learning process is able to hone students' analytical skills and creativity through implementing the syntax of the learning process starting from the ability to plan, implement, test, and be able to carry out continuous control and make improvements if something goes wrong. (Cheng, 2016; Nizwardi, 2016; Syafiq, 2014)

The use of project-based practice modules can increase the active role of students in practice, because the use of project-based practice modules provides a challenge to students in increasing their active role, motivation and creativity so that in the end it is expected to improve student learning abilities / learning outcomes in learning outcomes that have been achieved. set in the Domestic Electrical Installation practice course. (Azlan, 2015; Cheng, 2016).

\section{METHOD}

This research is a development research which based on the formulation of the problem and the research objectives to be achieved. In this development research, the product produced is in the form of a project-based practice module which is created and designed by adopting the steps of a project-based learning model. This development research was chosen because development research is research that is used or carried out to produce certain products and to test the effectiveness of the products that are made and developed. So that the products produced in this study really meet the requirements of testing and development before they can be applied in the learning process.

The development model chosen in this study is the 4-D model because the development model is considered to have a systematic procedure, according to the background of the problem, the formulation of the problem and the research objectives to be achieved. In addition, this development model was chosen because it was considered in accordance with the characteristics of the steps in developing the products that would be produced in this study.

\section{RESULT}

The product in the form of a practical module that has been completed based on the results of the final design needs to be carried out several feasibility tests before it can be applied in the learning process. one of them is validity testing conducted by experts called validators. The validator is the person assigned to assess the validity of the product being developed which has competence in the field of learning media and competence in the field of domestic electrical installation science. The goal is that the results of the assessment of the validity of the product being developed can be justified. This project-based practice module learning media validation activity is carried out by consulting the practice module that has been developed with the validator. The validator will pay attention and read the overall content of the developed practice module, then the validator is asked to fill in the validity instrument according to the validated 
aspects, on this validity sheet there is also an entry to write suggestions and input from the validator. The result of filling out the validity instrument becomes the reference for determining the validity of the product being developed.

\section{A. Validation of Content/Material Aspects}

The validation of this material was carried out by two experts on Domestic Electrical Installation learning materials. The purpose of material expert validation is to determine the accuracy and suitability between aspects of the content of the learning material and the product being developed. So that the product is really able to become a practical learning media in accordance with the learning material. Validation assessment data is obtained after the validator provides an assessment of the validity instrument that has been provided for the product developed after the validator is given the authority to read and pay attention to the overall content of the practice module.

The data obtained by the validator were then analyzed with the Aiken ' $\mathrm{V}$ validation analysis formula. Based on the results of the data analysis, it can be seen that the average $\mathrm{V}$ value obtained is 0.92 , which means that the project-based practice module is declared valid in the material aspect, apart from 11 items. which was validated based on the validity instrument of all items obtained a value of $\mathrm{V}$ $\geq 0.88$ which means valid. Where the highest $\mathrm{V}$ value is 1.00 and the lowest is 0.75 .

\section{B. Language Validation}

Language validation is validation of writing and the use of scientific language rules, this language validation ensures that the content of the developed practice module meets the criteria for scientific grammar and uses sentences that are in accordance with the rules of scientific writing so that it does not make it difficult for readers to understand the content and meaning of sentences used. Validation of this language aspect was carried out by two validators of Indonesian scientific grammar and language experts. Validation assessment data is obtained after the validator provides research through filling in the validity instrument provided. Filling in this instrument is done after the validator has observed and read the entire content of the project-based practice module.

The data from the validation test results by linguists were then analyzed using Aiken'S V analysis. Based on the results of the data analysis, it can be seen that the average $\mathrm{V}$ value obtained is 0.93, which means that the project-based practice module is declared valid in the language aspect, apart from 9 items that were validated based on the validity instrument all items obtained a value of $\mathrm{V} \geq$ 0.88 which means valid. Where the highest $\mathrm{V}$ value obtained is 1.00 and the lowest is 0.75 .

\section{Validation of Media and Design Experts}

Media validation is validation of the accuracy and suitability of products developed with the criteria for learning media especially for practical learning media and the feasibility of design to fulfill the function as a practical learning media. Validation of the media and design aspects was carried out by two validators of instructional media and design experts. Validation assessment data is obtained after the validator provides research through filling in the validity instrument provided. Filling in this instrument is done after the validator observes and reads the entire content of the project-based practice module.

The data from the media validation and design by instructional media experts were analyzed using Aiken'S V analysis. Based on the results of the data analysis, it can be seen that the average $\mathrm{V}$ value obtained is 0.891 , which means that the projectbased practice module is declared valid in the media and design aspects. Of the 12 items validated based on the validity instrument, all items obtained a value of $\mathrm{V} \geq 0.88$ which means valid. Where the highest $\mathrm{V}$ value obtained is 1.00 and the lowest is 0.75 .

\section{DISCUSSION}

Project-Based Practice Modules are compiled and developed based on a needs analysis of students and learning materials on the Domestic Installation Practice learning process. Domestic electrical installation practice is a practical work or workshopbased learning process where the learning process is more aimed at increasing the practical competence of students in certain fields. Broadly speaking, the purpose of the Domestic Installation Practice learning process is that students are able and master competence in planning, preparing, installing, and testing and conducting electrical installations at the domestic level such as residential installations, offices, school buildings and other domestic buildings. Based on these objectives, at least this learning process aims for students to master four competencies of expertise in the field of domestic installation, namely the competence of planning, preparation, installation, and testing and control.

The four main competencies that must be mastered by students after participating in the domestic installation learning process also require the implementation of a good learning process, namely the learning process that can help students achieve these learning objectives. One of the factors supporting the successful achievement of learning 
objectives for the practical learning process is the availability of good practice modules in accordance with the characteristics of the material and the learning process. The suitability of the practice modules used will affect the implementation and achievement of learning objectives. This fact is the reason for developing project-based practice modules because based on several studies, namely those conducted by Azlan (2015), Hamidi (2010), and Luki (2014) shows that the practice module by adopting project-based learning is effectively used for practical learning processes that emphasize more. practical competences for students.

The development of a project-based practice module is designed according to the analysis of the needs and problems found during the initial research observations. At this design stage, a practical module framework is designed to be developed by adopting project-based learning steps (Smith, 2015; Heinch, 2015). The framework in question is in the form of determining the topic, as well as the steps to carry out the learning process carried out by students during the learning process. The main characteristic of the practical module developed in this study is that the core student learning activities are divided into 4 learning activities, namely planning, preparation, installation, and testing activities. These 4 activities are the main features of project-based learning (Aginako-Arri, Garmendia-Mujika, Bezanilla-Albisua, \& Mendez, 2019; Chen \& Yang, 2019; Luo \& $\mathrm{Wu}, 2015)$. In addition, these 4 activities are also learning activities capable of supporting the achievement of key competencies in the domestic installation practical learning process. After the initial framework has been determined, the next step is to enter the drafting stage.

The preparation of a project-based practical module is carried out by referring to the initial module framework defined in the previous stages. The creation and preparation of this project-based practice module is carried out by referring to the initial framework that was completed at the design stage, the practice module is prepared for 16 learning meetings, for initial meetings 1 to 11 in the form of small-scale projects and for 12 to 16 learning meetings are given Large-scale projects, in which students are asked to be able to plan, prepare, install, and test the complete electrical installation of 1 building. The learning division in the form of small-scale projects at the beginning of the learning process then ends with a large-scale project at the final learning meetings is to train students gradually to adapt to this project-based learning process (Chow, 2014; Nazari, 2013; Mark, 2015).

In the development process, the Project-Based Practice Module has passed several stages of testing as a requirement before the product in the form of a practical module for implementing this practical learning implementation can be applied and used by both lecturers and students in the domestic installation practical learning process. One of the most important things in this test is the validity testing phase, which is the assessment of the level of truth which becomes a reference for the feasibility of a product being developed that can be applied in the learning process. This is because before a product can be tested and applied, it is necessary to test its validity first. Validity testing is done by asking for an assessment by an expert in accordance with the validation aspect which is assisted by the existence of an instrument in the form of a validity assessment sheet. This validation activity can be done repeatedly so that the results are obtained that the product is valid (Heinch,2015; Moriarty,2016).

The validity testing phase shows that the developed project-based practice module is valid for every aspect of validation, namely the content or material aspects, the learning media aspects, and the language aspects. With the validity of the three aspects, it proves that the project-based practice module has met the criteria of truth and validity as a learning medium in the practical learning process, especially in the domestic installation practice learning process. This is supported by several previous research results which show that after a project-based practice module in a learning process meets the validity criteria of a product based on its validation aspects, it can be said that the practice module can be tested to get other test results before the project-based practice module is correct. -truly applied in the learning process (Zulburmana; 2014; Chen \& Yang, 2019; Ergül \& Kargın, 2014) .

The results of this assessment indicate that the project-based practice module being developed has fulfilled the validity and truth as a practical learning medium. This is proven by the results of validity testing for all three aspects of validation. Thus, it can be said that the project-based practice module developed in the domestic installation practice learning process for vocational lecturers of the D III Electrical Engineering Study Program is valid in material, media, and language. This is supported by several previous research results which show that the practice module developed based on the characteristics of the material and the implementation of the learning process will meet the validity criteria as a learning medium.

\section{Conclusion}

The resulting product is a practical learning medium in the form of a project-based module that is 
valid in the Domestic Electrical Installation Practice learning process for students of the Electrical Engineering Study Program, Faculty of Engineering, Universitas Negeri Padang. This is proved because this project-based module has undergone validity trials, which are carried out by means of an assessment by a validator. This project-based practical module was developed for the domestic electrical installation practical learning process for one semester of learning.

\section{REFERENCES}

Aginako-Arri, Z., Garmendia-Mujika, M., BezanillaAlbisua, M. J., \& Mendez, E. S. (2019). Professional skills development in engineering education at the University of the Basque Country: Problem or project based on learning? Dyna (Spain). https://doi.org/10.6036/8720

Aiken, L. R. (1985). Three Coefficients for Analyzing the Reliability and Validity of Ratings. Educational and Psychological Measurement. 45, 131-142

Arief, Sardiman dkk. 2008. Media Pembelajaran (Pengertian Pengembangan Pemanfaatan). Jakarta: Raja Wali Press.

Ansyar, Rayandra. 2012. Kreatif Mengembangkan Media Pembelajaran. Jakarta: Gaung Persada.

Aqib, Zainal. \& Murtadlo, Ali. 2016. Kumpulan Metode Pembelajaran. Bandung: Satunusa

Azhar, Arsyad. 2013. Media Pembelajaran. Jakarta: Raja Wali Press.

Azlan, Nor. 2015. Comparison of the Training Effects of Project-Based Learning Model and Group Investigation on Increasing Learning Outcomes, in Physics Science Course”. ScienceDirect. Department of Education-Shahid Rajaee Teacher Training University, Iran

Burhan, Hadi. 2007. Media Pendidikan dan Penerapannya. Jakarta: Graha Persada.

Burhan, Kusuma. 2012. Merancang Media Pembelajaran Menggunakan Macromedia Flash. Jakarta : Bumi Aksara.

Chen, C. H., \& Yang, Y. C. (2019). Revisiting the effects of project-based learning on students' academic achievement: A meta-analysis investigating moderators. Educational Research Review, 26(January), 71-81. https://doi.org/10.1016/j.edurev.2018.11.001

Chen, W. K. 2016. “Increasing the students' learning process through Project-Based Learning Model. ScienceDirect. UTM Malaysia

Daryanto. 2013. Media Pembelajaran: Peranannya Sangat Penting dalam Mencapai Tujuan Pembelajaran. Yogyakarta: Gava Media
Deni, Dermawan. 2012. Inovasi Pendidikan. Bandung: P.T. Remaja Rosdakarya Offset.

Ergül, N. R., \& Kargın, E. K. (2014). The Effect of Project based Learning on Students' Science Success. Procedia - Social and Behavioral Sciences, $\quad$ 536, 541. https://doi.org/10.1016/j.sbspro.2014.05.371

Hamidi, Farideh. 2010. "Comparison of the Training Effects of Interactive Multimedia (CDs) and NonInteractive Media (films) on Increasing Learning Outcomes, in Physics Science Course". ScienceDirect. Department of Education-Shahid Rajaee Teacher Training University, Iran.

Heinich, dkk. 2005. Instructional Technology and Media for Learning. New Jersey, Columbus, Ohio: Pearson Merrill Prentice Hall. Upper Saddle River

Kemp \& Dayton. 1985. Planning \& Producing Instructional Media. New York: Harper \& Row Publishers.

Latuheru, John D. 1988. Media Pembelajaran Dalam Proses Belajar-Mengajar Masa Kini. Jakarta: Departemen Pendidikan dan Kebudayaan

Luki, Hamdani. 2014. "Pengembangan Modul Praktek Berbasis Proyek pada Mata Pelajaran Pemeliharaan Motor Listrik Kelas XII Jurusan Teknik Ketenagalistrikan di SMK Negeri 2 Lubuk Basung ”. Tesis. PPS FT-UNP

Luo, Y., \& Wu, W. (2015). Sustainable Design with BIM Facilitation in Project-based Learning. Procedia Engineering, 118, 819-826. https://doi.org/10.1016/j.proeng.2015.08.519

Made, Wena. 2009. Strategi Pembelajaran Inovatif Kontemporer: Suatu Tinjauan. Konseptual Operasional. Jakarta: PT. Bumi Aksara.

Martoyo. Susilo.. 2011. Manajemen Sumber Daya Manusia, BPFE. Yogyakarta.

Miarso, Yusuf Hadi, 1984, teknologi KOmunikasi Pendidikan. Jakarta : CV. Rajawali

Munandar, Utami. 2014. Pengembangan Kreativitas Anak Berbakat. Jakarta: Rineka Cipta

Nana, Sudjana. 2004. Penelitian dan Penelitian Pendidikan. Bandung: Sinar Bandung Algesindo.

Notoatmodjo, Soekidjo. 2009. Pengembangan Sumber Daya Manusia.Jakarta : PT. Rineka

Oemar, Hamalik. 2008. Perencanaan Pembelajaran Berdasarkan Pendekatan Sistem. Jakarta : Bumi Aksara.

Prayitno. 2009. Dasar Teori dan Praktis Pendidikan. Jakarta: Grasindo

Purnowo. 2009. Media dalam Proses Pembelajaran. Bandung : Alfabeta.

Riduwan. 2010. Skala Pengukuran Variabel-Variabel Penelitian. Bandung: Alfabeta. 
Rusman. 2012. Belajar dan Pembelajaran Berbasis Komputer. Bandung: Alfabeta

Rusman dkk. 2011. Pembelajaran Berbasis Teknologi Informasi dan Komunikasi. Jakarta: Rajawali Pers

Smaldino, Sharon E, dkk. 2012. Instructional Technology \& Media For Learning.Pearson Education. Inc.

Smith, Richard, 2015. "Enhancing students' learning process through Project-Based Learning Model: New opportunities for collaborative learning”. ScienceDirect. UTM Malaysia

Sugiyono. 2012. Metode Penelitian Pendekatan Kualitatif, Kuantitatif dan R\&D. Bandung: Alfabeta.
Suharsimi, Arikunto. 2007. Dasar-dasar Evaluasi Pendidikan. Jakarta : Bumi Aksara

Suyono. 2010. Dasar-dasar Pendidikan Kejuruan.Jakarta: Graha Media Persada

The George Lucas Educational Foundation. 2005. Intructional Modul prakteke Project Based Learning. New York : MC Grown Hill.

Trianto. 2009. Mendesain Model Pembelajaran Inovatif Progresif. Jakarta : Kencana. 